\title{
Engineering Students Motivation on Multinational Projects: A Comparison Based on Interest, Value, and Gender
}

\author{
Ivan Esparragoza ${ }^{1}$, Jared Ocampo $^{2}$, Jorge Rodriguez ${ }^{3}$, Sheila Lascano ${ }^{4}$, Uladeislau Ivashyn ${ }^{1}$, Carlos Sacchelli $^{5}$, \\ Roberto Vigano6, and Jorge Duque ${ }^{7}$ \\ ${ }^{1}$ The Pennsylvania State University, USA, iee1@psu.edu, uxi1@psu.edu \\ ${ }^{2}$ Universidad Tecnológica Centroamericana, Honduras, jared.ocampo@unitec.edu \\ ${ }^{3}$ West Michigan University, USA, jorge.rodriguez@wmich.edu \\ ${ }^{4}$ Universidad Técnica Federico Santa Maria, Chile, sheila.lascano@usm.cl \\ ${ }^{5}$ Universidade Federal de Santa Catarina, Brazil, carlos.sacchelli@gmail.com \\ ${ }^{6}$ Politenico di Milano, Italy, roberto.vigano@polimi.it \\ ${ }^{7}$ Escuela Superior Politécnica del Litoral, Ecuador, jduque@espol.ec
}

\begin{abstract}
In today's world, it has become very common to find engineers working on multinational projects. As a result, educational institutions need to prepare students to succeed in this global working environment by incorporating global collaborative projects as a learning experience. At the same time, students should be aware of the importance of this experience, recognize its benefit, and be motivated to participate on the projects. It is documented in the literature that students' interest and motivation are important factors contributing to the learning process in any discipline, and of particular importance when students are exposed to a projectbased educational experience in a collaborative and multinational context. Authors have used the multinational collaborative projects to prepare students with global competencies but no formal assessment of the impact of this experience has been done. As part of a formal evaluation of this experience, the main goal of this study is to determine the level of interest and perception of value of engineering students participating in a multinational collaborative project, and make a comparison of such indicators based on gender. For this purpose, a survey based on the Intrinsic Motivation Inventory (IMI) was given to students before starting their participation in the multinational projects. The data collected provides information in five constructs which are: interest, perceived competence, pressure, perceived choice, and value. These constructs provide a perception about students' interests, beliefs, and feelings about the international project that reflect their level of motivation to carry on the tasks.

Keywords: Student Motivation, Multinational Project, Gender Comparison, International Collaboration, Interest and Value.
\end{abstract}

Digital Object Identifier

(DOI):http://dx.doi.org/10.18687/LACCEI2016.1.1.268

ISBN: 978-0-9822896-9-3

ISSN: 2414-6390

$14^{\text {th }}$ LACCEI International Multi-Conference for Engineering, Education, and Technology: "Engineering Innovations for Global Sustainability", 20-22 July 2016, San José, Costa Rica. 


\title{
Engineering Students Motivation on Multinational Projects: A Comparison Based on Interest, Value, and Gender
}

\author{
Ivan Esparragoza ${ }^{1}$, Jared Ocampo ${ }^{2}$, Jorge Rodriguez ${ }^{3}$, Sheila Lascano ${ }^{4}$, Uladeislau Ivashyn ${ }^{1}$, Carlos \\ Sacchelli $^{5}$, Roberto Vigano ${ }^{6}$, and Jorge Duque ${ }^{7}$ \\ ${ }^{1}$ The Pennsylvania State University, USA, iee1@psu.edu, uxi1@psu.edu \\ ${ }^{2}$ Universidad Tecnológica Centroamericana, Honduras, jared.ocampo@unitec.edu \\ ${ }^{3}$ West Michigan University, USA, jorge.rodriguez@wmich.edu \\ ${ }^{4}$ Universidad Técnica Federico Santa Maria, Chile, sheila.lascano@usm.cl \\ ${ }^{5}$ Universidade Federal de Santa Catarina, Brazil, carlos.sacchelli@gmail.com \\ ${ }^{6}$ Politenico di Milano, Italy, roberto.vigano@polimi.it \\ ${ }^{7}$ Escuela Superior Politécnica del Litoral, Ecuador, jduque@espol.ec
}

\begin{abstract}
In today's world, it has become very common to find engineers working on multinational projects. As a result, educational institutions need to prepare students to succeed in this global working environment by incorporating global collaborative projects as a learning experience. At the same time, students should be aware of the importance of this experience, recognize its benefit, and be motivated to participate on the projects. It is documented in the literature that students' interest and motivation are important factors contributing to the learning process in any discipline, and of particular importance when students are exposed to a project-based educational experience in a collaborative and multinational context. Authors have used the multinational collaborative projects to prepare students with global competencies but no formal assessment of the impact of this experience has been done. As part of a formal evaluation of this experience, the main goal of this study is to determine the level of interest and perception of value of engineering students participating in a multinational collaborative project, and make a comparison of such indicators based on gender. For this purpose, a survey based on the Intrinsic Motivation Inventory (IMI) was given to students before starting their participation in the multinational projects. The data collected provides information in five constructs which are: interest, perceived competence, pressure, perceived choice, and value. These constructs provide a perception about students' interests, beliefs, and feelings about the international project that reflect their level of motivation to carry on the tasks.

Keywords: Student Motivation, Multinational Project, Gender Comparison, International Collaboration, Interest and Value.
\end{abstract}

\section{INTRODUCTION}

Collaborative design is increasingly becoming a central activity in the design of every product. In fact, because of the growing complexity of today's products, their development requires to integrate knowledge and skills across disciplines and organizations with great level of engagement and collaboration between diverse parties. Working on a collaborative environment provides the advantages of having complementary resources, information and ideas that compensate for the limitations of a design done individually. The expected result is a product that could not have been achieved by any individual acting alone.
The surge of information technologies, in particular communication capabilities and cloud computing, improves the capacity of sharing information across teams of designers located around the world, and provides the infrastructure necessary for an integrated and distributed engineering environment [1]. However, working on multi- or inter disciplinary projects is inherently challenging, and effective collaboration may require new ways to share information. These challenges "include aspects such as differences in language, culture, education, and government regulations, as well as teams working across different time zones around the world" [2]. As result of these challenges, there is a growing demand for professionals who are able to effectively and efficiently communicate and collaborate with partners from different countries and cultures [3].

It is evident that there is an educational challenge regarding training experiences offered to students so that they acquire the skills necessary to operate in an interdisciplinary and intercultural collaborative environment. As a result, many engineering programs are incorporating educational experiences to better prepare students for the global working environment. Multinational collaborative projects are a good example of those experiences incorporated through engineering curricula to promote the development of global competencies in students in addition to the technical knowledge of a particular discipline. These projects are characterized by having teams geographically dispersed but working on a common design project. A multinational collaborative project involving students from the US, Latin America and Europe [4] is used as a subject of this study. A motivation to introduced this project comes from the notion that while international projects offer new opportunities for diversification and expansion, they also introduce new risks because is a new market, cultural, administrative, geographic, and economic differences between the organization's home market and the project's host country must be taken into account [5]. Then, students must be prepared also to understand and deal with these challenges.

Digital Object Identifier (DOI): http://dx.doi.org/10.18687/LACCEI2016.1.1.268

ISBN: 978-0-9822896-9-3

ISSN: $2414-6390$

$14^{\text {th }}$ LACCEI International Multi-Conference for Engineering, Education, and Technology: "Engineering Innovations for Global Sustainability”, 20-22 July 2016, San José, Costa Rica. 
The motivation of students is a key issue to succeed in any academic task. This is especially true in practical experiences such as international collaborative projects where students must be motivated to spend time to share ideas and information, and work on the project with foreign colleagues even when there is no explicit or immediate assessment performed. That is, students have to be intrinsically motivated, meaning that their source of motivation is in the performance of the task itself [6]. The design task should be such that students feel intrinsically motivated to behave in proactive, open minded and collaborative fashion, the expected level of effort is high, and the expected level of persistence to arrive at an acceptable final design is high as well. Motivation of students needs to be across the curriculum, since there is a need at upper class levels [7], but it is important to consider how to best support early year engineering students' motivation and self-regulating learning [8]. In these years is when students are more likely to drop out [9].

Additionally, the diversity in the teams is claimed as important aspect in the development of design tasks. In some engineering programs, the participation of female students is low [10]. Segregation that is observed in teamwork, including interaction based on gender, could result in possible reduction in the motivation of a team. According to Scot (1999) [11], the gender is a useful category of historical analysis, and typically is utilized to represent the role of women in different fields. However, in this study the term gender is used to introduce a relational notion and is only a category of analysis, and it does not suggest a differentiation by gender. The aim of this paper is to determine the level of motivation of engineering students participating in a multinational collaborative project and make a comparison based on gender.

\section{BACKGROUND}

There has been an adamant societal urge to advance the knowledge of the contemporary engineering students specifically by commencing explicit teachings of international collaboration within the engineering field. Several institutions located in Latin America have already begun to answer the call to create an internationally prepared engineer. Organizations such as the Latin American and Caribbean Consortium of Engineering Institutions (LACCEI), the Ibero American Science and Technology Education Consortium (ISTEC), the Asociación Ibero-Americana de Instituciones de Enseñanza de la Ingeniería (ASIBEI), and Engineering for the Americas (EftA) "promote the formation of world-class engineers for the Americas as well as an assortment of resources and opportunities that facilitate the participation of faculty, staff, and students from Latin America and the Caribbean in a variety of engineering education experiences” [12].

A collaborative network of institutions from the Americas and Italy has developed and implemented collaborative multinational design projects as part of academic experiences for their students. The main goal of these projects is to foster international collaboration and to offer an opportunity to the students to develop professional skills through international teamwork effort in the solution of a design problem. However, a real challenge of this practice has been to create an effective interaction among the students participating in this type of projects and to maintain the flow of information, and students' engagement in the project and in their learning [13].

Some tools to determinate motivation have been proposed like the Work Preference Inventory (WPI), which is designed to assess individual differences in intrinsic and extrinsic motivational orientations [14]. The Academic Motivation Scale (AMS), has allowed researchers to distinguish relevant associations between motivation and academic variables [15]. A 24-factor scale of motivation is proposed by Waugh, R. F., (2002) [16], with attitude items linked to behaviour items, based on a conceptual model of Motivation, involving Striving for Excellence (Standards, Goals, Tasks, Effort, Values and Ability), Desire to Learn (Interest, Learning from Others and Responsibility for Learning), and Rewards (Extrinsic, Intrinsic and Social).

Motivation theories incorporate a wide array of contributing factors; modern theories most relevant to engineering pertain to goals, values, and expectations [17]. Value models of motivation [18], indicates that expectations of success and the value placed on success determine motivation to achieve, and directly influence performance, persistence, and task choice. It is evident that those who persist in engineering have different motivation profiles than those who do not. There is a shift in students' motivational profiles over the course of an academic year (decreased expectancy, increased future and present perceptions) [19]. Another research demonstrated that expectancy and future time perspective frameworks may be limited at identifying motivational differences between engineering majors [20].

\section{PROPOSED APPROACH}

This study investigates existing differences in the interest and value perceived by students towards their participation in a multinational project with particular emphasis to the effect of students' gender, taking into consideration that interest and value are two of the constructs used to evaluate motivation of students.

The multinational collaborative project used in this study follows the parallel projects approach in which teams from different countries work on the same design project, and clusters of collaboration are formed for the international teams to exchange information and enrich the final conceptual design. Clusters are created in such a way that teams formed on each participating institution are paired with teams from other countries to enforce exchange of information and collaborative work. The interaction of the students is expected to take place using the formal means of communication that have been established for the collaboration and they are: audio-video conferences (Adobe Connect), email, and a cloud storage application selected for the project. Additionally,

$14^{\text {th }}$ LACCEI International Multi-Conference for Engineering, Education, and Technology: "Engineering Innovations for Global Sustainability”, 20-22 July 2016, San José, Costa Rica. 
teams are allowed to use informal means of communication to keep the interaction active during the project and this includes social media, texting, cellular phones and other online communication tools as the teams consider appropriate. The projects last for eight weeks and teams are required to interact for at least five weeks including four scheduled videoconferences.

The instrument used for measuring interest and value in this study is based on the Intrinsic Motivation Inventory (IMI). This is an instrument that aims to assess motivation in a broad array of situations and contexts and is rooted in SelfDetermination Theory [21]. This instrument has been used in research focused on intrinsic motivation and self-regulation in many fields such as sports activities, reading, computer activities, performance of puzzles, and training and education. But in all these studies the IMI versions used varied in subscales and items depending on the characteristics of tasks and participants [22]. A version of IMI was designed for this study, and it consisted of 27 questions on five constructs: interest, perceived competence, pressure, perceived choice, and value.

The data used for this study was collected during the collaboration that took place during the Fall 2015 for eight weeks between October and December. In this case, 54 international teams from seven different institutions representing six countries were grouped in 12 clusters. Six clusters had five international teams and six clusters had four international teams, as can be seen in Table I. The project during the Fall 2015 consists on the design of an appropriate workspace for prototyping with hand-tools. The following requirements were defined for the project: the workplace was to accommodate up to four people working simultaneously; workers with various types of disabilities should be able to use the facility; workbenches were to be utilized for prototyping and tools/materials storage; workbenches were to be installed in $34 \mathrm{~m}^{2}$ room with the footprint of the workbenches limited to a maximum of $50 \%$ of the room space.

TABLE I

CLUSTERS TEAM DISTRIBUTION

\begin{tabular}{|c|c|c|c|c|c|c|c|c|}
\hline Cluster & BR & CH & EC & HO & IT & US1 & US2 & Total \\
\hline 1 & & 2 & 1 & & & 1 & 1 & 5 \\
\hline 2 & & 2 & 1 & & & 1 & 1 & 5 \\
\hline 3 & & 2 & 1 & & & 1 & 1 & 5 \\
\hline 4 & & 2 & 1 & & & 1 & & 4 \\
\hline 5 & & 2 & 1 & & & 1 & & 4 \\
\hline 6 & & 2 & 1 & & & 1 & & 4 \\
\hline 7 & & 2 & & 1 & 1 & 1 & & 5 \\
\hline 8 & & 2 & & 1 & & 1 & 1 & 5 \\
\hline 9 & & 2 & & 1 & & 1 & 1 & 5 \\
\hline 10 & & 2 & & 1 & & 1 & & 4 \\
\hline 11 & & 2 & & 1 & & 1 & & 4 \\
\hline 12 & 1 & 2 & & & & 1 & & 4 \\
\hline Total & $\mathbf{1}$ & $\mathbf{2 4}$ & $\mathbf{6}$ & $\mathbf{5}$ & $\mathbf{1}$ & $\mathbf{1 2}$ & $\mathbf{5}$ & $\mathbf{5 4}$ \\
\hline
\end{tabular}

BR: Brazil/CH: Chile/EC: Ecuador/HO: Honduras/IT: Italy/US1: United States (University 1)/US2: United States (University 2)

The objective of this work is to determine the level of motivation of all students participating in a multinational collaborative project, as measured by their interest and expected value of this academic activity, and then make a comparison of those results based on gender. For this purpose, the designed version of the IMI survey was administered to all the students before starting their participation in the project. The following two research questions were addressed:

- Do students enter into the multinational collaborative project with a high interest and a high perception of value for this activity?

- Are there significant differences on interest and perception of value among students based on their gender?

\section{RESULTS}

Data was compiled from the administered questionnaire. There were a total of 32 questions, five demographics questions and 27 IMI-based questions. The first five questions allowed characterization of the population participating in the study. The next 27 questions used a seven-point Likert scale and are distributed in five constructs as follows: interest/enjoyment (7), perceived competence (5), pressure/tension (5), perceived choice (5), and value/usefulness (5).

The number of participants in the online questionnaire was 218. From those participants, a total of 185 students from six different countries were considered valid surveys. The majority of invalid surveys were incomplete surveys (24) and same numerical answer for all questions (6). The participants were $87 \%$ male $(n=161)$ and $13 \%$ female $(n=24)$. Table II shows a summary of the distribution of the population by gender, Table III shows the distribution by country and Table IV shows the distribution by class standing of students

In order to evaluate the consistency of the data collected for the constructs of motivation, a Cronbach's alpha analysis was conducted. The Cronbach's alpha indexes are shown in Table V. It is observed from these results that, although the entire instrument is considered consistent, the two constructs being evaluated (i.e., interest and value) have the highest alpha coefficients, which is very acceptable. Two other constructs, pressure and perceived choice, were below the 0.7 threshold value [23]. A further analysis revealed that three questions, one for the Pressure construct and two for the Perceived Choice construct, were bringing the Cronbach's alpha number below 0.7. If those questions are removed from the analysis, the value for Pressure goes up to 0.752 and the value for Perceived Choice goes up to 0.728 . It is possible that the referenced questions where not clearly understood by students and that could be the reason why they yielded a low Cronbach's alpha. Therefore, those questions were removed from the questionnaire to perform the analysis using reliable data. 
TABLE II

GENDER DISTRIBUTION

\begin{tabular}{|c|c|c|}
\hline Gender & Frequency & Percent (\%) \\
\hline Male & 161 & 87.0 \\
\hline Female & 24 & 13.0 \\
\hline Total & $\mathbf{1 8 5}$ & $\mathbf{1 0 0 . 0}$ \\
\hline
\end{tabular}

TABLE III

GEOGRAPHICAL DISTRIBUTION

\begin{tabular}{|c|c|c|}
\hline Country & Frequency & Percent (\%) \\
\hline Brazil & 4 & 2.2 \\
\hline Chile & 49 & 26.5 \\
\hline Ecuador & 33 & 17.8 \\
\hline Honduras & 28 & 15.1 \\
\hline Italy & 4 & 2.2 \\
\hline USA & 67 & 36.2 \\
\hline Total & $\mathbf{1 8 5}$ & $\mathbf{1 0 0 . 0}$ \\
\hline
\end{tabular}

TABLE IV

CLASS STANDING DISTRIBUTION

\begin{tabular}{|c|c|c|}
\hline Class Standing & Frequency & Percent (\%) \\
\hline First Year & 46 & 24.9 \\
\hline Second Year & 44 & 23.8 \\
\hline Third Year & 19 & 10.3 \\
\hline Fourth Year & 53 & 28.6 \\
\hline Fifth Year of higher & 23 & 12.4 \\
\hline Total & $\mathbf{1 8 5}$ & $\mathbf{1 0 0 . 0}$ \\
\hline
\end{tabular}

TABLE V

CRONBACH'S ALPHA RESUlTS

\begin{tabular}{|c|c|c|}
\hline Scale & Cronbach's alpha & No. of Items \\
\hline All instrument & 0.856 & 27 \\
\hline Interest/Enjoyment & 0.931 & 7 \\
\hline Value/Usefulness & 0.884 & 5 \\
\hline Perceived Competence & 0.828 & 5 \\
\hline Pressure/Tension & 0.692 & 5 \\
\hline Perceived Choice & 0.608 & 5 \\
\hline
\end{tabular}

The research questions that are analysed using the results from the questionnaire as follows:

- Research Question 1: Do students enter into the multinational collaborative project with a high interest and a high perception of value for this activity?

To test this research question, two hypothesis were proposed, the first one $\left(\boldsymbol{H}_{1}\right)$ states that students enter into the multinational collaborative project with high interest. To measure if this is true, the construct "interest/enjoyment" needs to be high as this subscale is considered the self-report measure of intrinsic motivation of the Intrinsic Motivation Inventory (IMI). Then, this can be measured in the following way:

$$
\boldsymbol{H}_{1}: \boldsymbol{\mu}_{\text {Interest }} \geq 70 \%
$$

where:

$$
\begin{aligned}
& \text { Interest }= \\
& \frac{Q 6+Q 11+Q 14+Q 17+(8-Q 22)+Q 26+Q 29}{49}
\end{aligned}
$$

With Q6, Q11, Q14, Q17, Q22, Q26, and Q29 correspond to the questions for the interest construct. Note that the score for Q22 was reversed in this case because the statement of the question from the IMI inventory is in the negative direction (i.e., not interested in the project). The reverse score is obtained by subtracting the original score from the maximum score in the survey ( 7 ) plus one (1), that is, from eight $(7+1=8)$ in this case.

The second hypothesis $\left(\boldsymbol{H}_{2}\right)$ is that students enter into the multinational collaborative project with the belief that the experience will be of value for their professional careers. To measure if this is true, the construct "value/usefulness" needs to be high. Then, this can be measured in the following way:

$$
\boldsymbol{H}_{2}: \boldsymbol{\mu}_{\text {Value }} \geq 70 \%
$$

where:

$$
\text { Value }=\frac{Q 10+Q 15+Q 19+Q 24+Q 32}{35}
$$

With Q10, Q15, Q19, Q24, and Q32 correspond to the questions for the value construct.

Using the equations presented previously and the data from the survey, the results obtained for Hypotheses 1 and 2 are summarized in Table VI. Then, according to the instrument used (survey), in general terms students displayed a high level of intrinsic motivation towards their participation in the multinational collaborative design project and the majority of them expected this experience to be very useful and of great value for their education. This can be seen by the high level of interest (74\% of the maximum possible score) and of expected value and usefulness ( $83 \%$ of the maximum possible score) they perceived.

TABLE VI

HYPOTHESIS 1 AND 2 RESULTS

\begin{tabular}{|c|c|c|c|c|}
\hline Constructs & $\begin{array}{c}\text { Max. Score } \\
\text { Possible }\end{array}$ & $\begin{array}{c}\text { Average } \\
\text { Score }\end{array}$ & $\begin{array}{c}\text { Obtained } \\
\text { Percent }(\%)\end{array}$ & Decision \\
\hline Interest $\left(\boldsymbol{H}_{\mathbf{1}}\right)$ & 49 & 36.5 & 74 & $\begin{array}{c}\text { Retain null } \\
\text { hypothesis }\end{array}$ \\
\hline Value $\left(\boldsymbol{H}_{\mathbf{2}}\right)$ & 35 & 29.1 & 83 & $\begin{array}{c}\text { Retain null } \\
\text { hypothesis }\end{array}$ \\
\hline
\end{tabular}

- Research Question 2: Are there significant differences on interest and perception of value among students based on their gender?

To test this research question based on gender, two more hypothesis were proposed. The third hypothesis $\left(\boldsymbol{H}_{3}\right)$ states that male and female students have similar interest towards the multinational collaborative project. To measure if this is true, an independent-sample $t$-test needs to be performed (small sample) to see if there are significant differences in the means of the variable "interest/enjoyment". Then, this can be measured in the following way:

$$
\boldsymbol{H}_{3}: \boldsymbol{\mu}_{\text {Interest (MALE) }}=\boldsymbol{\mu}_{\text {Interest (FEMALE) }}
$$

Similarly, the forth hypothesis $\left(\boldsymbol{H}_{4}\right)$ states that male and female students have a similar belief that the multinational collaborative project will be of value for their professional

$14^{\text {th }}$ LACCEI International Multi-Conference for Engineering, Education, and Technology: "Engineering Innovations for 
career. To measure if this is true, an independent-sample $t$-test is performed in the following way:

$$
\boldsymbol{H}_{\mathbf{4}}: \boldsymbol{\mu}_{\text {Value (MALE) }}=\boldsymbol{\mu}_{\text {Value (FEMALE) }}
$$

Using the data from the survey, the results are summarized in Table VII that shows the group statistics and Table VIII that shows the Levene and $t$-tests.

TABLE VII

GROUP STATISTICS

\begin{tabular}{|c|c|c|c|c|c|}
\hline Constructs & Gender & $\mathrm{n}$ & Mean & $\begin{array}{c}\text { Std. } \\
\text { Deviation }\end{array}$ & $\begin{array}{c}\text { Std. Error } \\
\text { Mean }\end{array}$ \\
\hline \multirow{2}{*}{ Interest } & Male & 161 & 36.224 & 8.9043 & 0.7017 \\
\cline { 2 - 6 } & Female & 24 & 38.208 & 8.8316 & 1.8027 \\
\hline \multirow{2}{*}{ Value } & Male & 161 & 28.783 & 5.2173 & 0.4112 \\
\cline { 2 - 6 } & Female & 24 & 31.208 & 4.1070 & 0.8383 \\
\hline
\end{tabular}

From the Levene's test results (Table VIII), it can be seen that in both cases the variability of the data is about the same (significance value above 0.05). From the results of the independent-sample $t$-test, $\boldsymbol{H}_{3}$ cannot be rejected since the significance value is greater than 0.05 , which means that the motivation is the same for male and females students. However, from the same results it can be seen that there is a statistically significant difference between the female and male students' perception of value/ usefulness of this activity (significance value below 0.05). In fact, according to the group statistics female students think more positively regarding the value of this activity than male students. Therefore, hypothesis $\boldsymbol{H}_{\mathbf{4}}$ is rejected.

TABLE VIII

LEVENE AND T-TEST RESULTS

\begin{tabular}{|c|c|c|c|c|c|c|c|}
\hline & & \multicolumn{2}{|c|}{$\begin{array}{l}\text { Levene's Test } \\
\text { for Equality of } \\
\text { Variances }\end{array}$} & \multicolumn{3}{|c|}{$\begin{array}{l}t \text {-test for Equality of } \\
\text { Means }\end{array}$} & \multirow{2}{*}{ Decision } \\
\hline & & $\mathrm{F}$ & Sig. & $\mathrm{t}$ & $\mathrm{df}$ & $\begin{array}{c}\text { Sig. } \\
2- \\
\text { tails }\end{array}$ & \\
\hline \multirow[t]{2}{*}{$\begin{array}{c}\text { Interest } \\
\left(\boldsymbol{H}_{3}\right)\end{array}$} & $\begin{array}{c}\text { Equal } \\
\text { variances }\end{array}$ & 0.034 & 0.853 & -1.020 & 183 & $\begin{array}{l}0.3 \\
09\end{array}$ & \multirow[b]{2}{*}{$\begin{array}{l}\text { Retain null } \\
\text { hypothesis }\end{array}$} \\
\hline & $\begin{array}{c}\text { Not } \\
\text { equal } \\
\text { variances }\end{array}$ & & & -1.026 & 30.398 & $\begin{array}{c}0.3 \\
13\end{array}$ & \\
\hline \multirow[t]{2}{*}{$\begin{array}{c}\text { Value } \\
\left(\boldsymbol{H}_{4}\right)\end{array}$} & $\begin{array}{c}\text { Equal } \\
\text { variances }\end{array}$ & 1.169 & 0.281 & -2.177 & 183 & $\begin{array}{l}0.0 \\
31\end{array}$ & \multirow{2}{*}{$\begin{array}{l}\text { Reject null } \\
\text { hypothesis }\end{array}$} \\
\hline & $\begin{array}{c}\text { Not } \\
\text { equal } \\
\text { variances }\end{array}$ & & & -2.598 & 35.105 & $\begin{array}{l}0.0 \\
14\end{array}$ & \\
\hline
\end{tabular}

\section{CONCLUSIONS}

In this work, an IMI-based questionnaire was defined and administered to determine the level of motivation of engineering students participating in a multinational collaborative project. Comparison based on gender was performed. According to the obtained results the following may be concluded:

- on interest/enjoyment, students showed a high level of interest/enjoyment towards their participation in the multinational collaborative project (74\%)
- on value/usefulness, students had a similar belief that the multinational collaborative project will be of value/usefulness for their professional careers (83\%)

- on gender, male and females students have the similar motivation towards the multinational collaborative project. However female students believe that participation in a multinational project is of higher value than male students.

It is possible that the idea of getting to know students from other countries and to have a new experience outside the classroom and regular structured learning process generates interest and it is exciting to them. Since the majority of students are conscious of the challenges that globalization poses to current business endeavours, this knowledge may be the reason why they feel this experience will be of great value to their future careers.

\section{REFERENCES}

[1] Pfleeger, S. L., \& Atlee, J. M. (1998). Software engineering: theory and practice. Pearson Education India.

[2] Törlind, P. (2016). Collaborative Design Journal of the Indian Institute of Science,95(4), 353-364

[3] DeVoss, D., Jasken, J., \& Hayden, D. (2002). Teaching intracultural and intercultural communication. A critique and suggested method. Journal of Business and Technical Communication, 16, 69-94.

[4] Esparragoza, I. E., Nunez, J., Lascano, S., Ocampo, J. R., Vigano, R., \& Duque, J. (2015). Assessment of interaction in multinational projects: A comparison based on geographical location. International Conference on Interactive Collaborative Learning (ICL), pp. 347-354.

[5] Berteaux, F., Javernick-Will, A., (2015) "Adaptation and Integration for Multinational Project-Based Organizations”, Journal of management in engineering, vol. 31, no. 6, Nov. 2015.

[6] George, J. M., Jones, G. R., \& Sharbrough, W. C. (1996). Understanding and managing organizational behavior: Addison-Wesley Reading, MA.

[7] Sheppard, S., Gilmartin, S., Chen, H. L., Donaldson, K., Lichtenstein, G., Eris, O., Lande,M., and Toye, G., (2010) " Exploring the Engineering Student Experience: Findings from the Academic Pathways of People Learning Engineering Survey (APPLES) (TR-10-01)”. Seattle, WA: Center for the Advancement for Engineering Education.

[8] Nelson, K., Shell, D. F., Husman, J., Fishman, E. J., Soh, L. K., (2015) "Motivational and Self-Regulated Learning Profiles of Students Taking a Foundational Engineering Course," Journal of Engineering Education, vol. 104, no 1, pp. 74-100, Jan. 2015.

[9] Gainen, J., (1995)“Barriers to success in quantitative gatekeeper courses", New Directions for Teaching and Learning, vol. 1995, no.61, pp 5-14.

[10] Guevara, P. G., (2002). Las carreras en ingeniería en el marco de la globalización: una perspectiva de género. Revista Latinoamericana de Estudios Educativos (México), 32(3), 91-105.

[11] Scott, J. W., (1999). Gender as a useful category of historical analysis. Culture, Society and Sexuality: A Reader, 57-75.

[12] Esparragoza, I., Larrondo Petrie, M. M., Jordan, R., \& Paez Saavedra, J. (2007). Forming the Global Engineer for the Americas: Global Educational Experiences and Opportunities Involving Latin America and the Caribbean. AC 2007-576, (p. 20).

[13] Esparragoza, I. E., Lascano Farak, S. K., \& Ocampo, J. R. (2014). Assessing interactions among students geographically disperse during multinational design projects. ASEE, 121st Annual Conference, (p. 12). Indianapolis.

[14] Amabile, T. M., Hill, K. G., Hennessey, B. A., Tighe, E. M., (1994) "The work preference inventory: assesing intrinsic and extrinsic motivational orientations”, Journal of Personality and Social Psychology, Vol. 66 no. 5, pp. 950- 967, May 1994.

[15] Stover,J. B., Iglesia, G., Ria, A., Boubeta, L., Liporace, M. F., (2012) "Academic Motivation Scale: adaptation and psychometric

$14^{\text {th }}$ LACCEI International Multi-Conference for Engineering, Education, and Technology: "Engineering Innovations for 
analyses for high school and college students,” Psychol Res Behav Manag. Vol 5, pp 71-83, Jul 2012.

[16] Waugh, R. F., (2002) "Creating a scale to measure motivation to achieve academically: Linking attitudes and behaviours using Rasch measurement,” British Journal of Educational Psychology, Vol. 72, no.1, pp. 65-86, March 2002.

[17] Svinicki, M. (2004). Learning and motivation in the post secondary classroom. Bolton, MA: Anker Publishing.

[18] Eccles, J., Adler, T., Futterman, R., Goff, S., Kaczala, C., \& Meece, J. (1983). Expectancies, values, and academic behaviors. San Francisco, CA: W. H. Freeman.

[19] Benson, L., \& Morkos, B. (2011). Student Motivation and Learning in Engineering. ASEE 120th Annual Conference, (p. 13). Atlanta.

[20] Jones, B., Paretti, M., Hein, S., \& Knott, T. (2009). An Analysis of Motivation Constructs with First-Year Engineering Students: Relationships Among Expectancies, Values, Achievement, and Career Plans. Journal of Engineering Education, 319-36.

[21] Deci, E. L., Ryan, R. M., (2000) "The "What" and "Why" of goal pursuits: Human needs and self-determination of behavior," Psychological Inquiry, vol. 11, no.4, pp. 227-268, 2000.

[22] Monteiro, V., Mata, L., Peixoto, F., (2015) "Intrinsic Motivation Inventory: Psychometric Properties in the Context of First Language and Mathematics Learning," Psicol. Reflex. Crit., vol. 28, no. 3, pp.434-443.

[23] Nunnally, J. C., and Bernstein, I. H., (1994) Psychometric Theory, McGraw-Hill, $3^{\text {rd }}$ Ed, 1994.

$14^{\text {th }}$ LACCEI International Multi-Conference for Engineering, Education, and Technology: "Engineering Innovations for Global Sustainability”, 20-22 July 2016, San José, Costa Rica. 